\title{
Phenotypic Study and Sensitivity to Anti-Infective Chemotherapy of Bacterial Strains Isolated from Cutaneous-Mucosal Infections
}

\author{
DELIA MIRA BERCEANU VADUVA ${ }^{1,2 \# ~, ~ D A N A ~ E M I L I A ~ V E L I M I R O V I C I ~}{ }^{1 *}$, MARCEL MIHAI BERCEANU VADUVA ${ }^{1,2 \#, ~}$ LIVIA STANGA $^{1 *}$, \\ HORATIU PETRESCU ${ }^{1}$, MARIA RADA ${ }^{1}$, DANIELA CIPU ${ }^{1}$, BIANCA MANUELA BERCEANU VADUVA ${ }^{1}$, MATILDA RADULESCU ${ }^{1,2}$ \\ ${ }^{1}$ University of Medicine and Pharmacy Victor Babes, 2 Eftimie Murgu Sq., 300041, Timisoara, Romania \\ ${ }^{2}$ Laborator Clinic Dr, Berceanu, 7 Teiului Str, 300659, Timisoara, Romania
}

\begin{abstract}
Skin- and mucosal infections, especially purulent, can often cause diagnostic and treatment problems. Therefore, we intend to conduct a microbiological study of isolated bacterial strains from ambulatory patients with various cutaneous-mucosal infections. In isolated strains we determined the sensitivity to antibiotics and we established the phenotypes of resistance in which they fall. We took in account 98 strains isolated by a private laboratory in Timisoara between January 2016 and December 2017. After bacterial identification, sensitivity testing to antibiotics was realized using Kirby-Bauer disc diffusion according to the CLSI standard. Antibiogram was performed for all strains except for Streptococcus pyogenes. By interpreting the antibiograms, the phenotypes of resistance were determined. Most infections were caused by Staphylococcus aureus. In order of frequency following strains were isolated: Staphylococcus aureus (75.52\%), Streptococcus pyogenes (11.22\%), Pseudomonas aeruginosa (7.14\%), E. coli (4.08\%) and Enterobacter spp. (2.04\%). S. aureus strains were resistant to penicillin in $94.60 \%$ of cases. We observed a higher sensitivity to oxacillin (87.84\%), tobramycin (86.49\%), gentamycin (87.84\%), ciprofloxacin (83.78\%) and clindamycin (89.20\%). Most strains of S. aureus were of phenotype Peni-R Meti-S (82.44\%). $12.16 \%$ were of phenotype Peni-R Meti-R (MRSA) and only 5.40\% were sensitive to betalactams (Peni-S Meti-S). Gram-negative bacilli strains (Pseudomonas aeruginosa, E. coli, Enterobacter spp.) were less resistant, all being wild strains. Determining antibiotic resistance phenotypes is necessary in order to be able to make the right decision when choosing anti-infectious treatment, but also to prevent the selection of multiresistant bacterial strains. The presence of MRSA at a rate of $12.16 \%$ is an alarm signal because the MRSA strains are multi-resistant to antibiotics with cross-resistance to the betalactams. Resistance usualy extends also to other classes of antibiotics. For a correct diagnosis and treatment, the results of the bacteriological testing need to be corroborated with the clinical signs.
\end{abstract}

Keywords: skin- and mucosal infections, resistance phenotypes, antibiotics, chemotherapeutical agents, MRSA

Skin infections and those of other soft tissues of the body, respectively of the subcutaneous tissues, fascia and muscles, especially the purulent ones, frequently occur in practice, causing difficulties of diagnosis and treatment [1-3]. They are characterized by great diversity, determined by both the large number of etiological agents that may be involved in the pathogenic process, the variety of occuring patterns and by the multitude of clinical aspects of the infectious processes [4- 6].

A simple differentiation of cutaneous-mucosal infections can be made based on the location and spread of the infection [3]. Differentiation of complicated cutaneousmucosal infections is often difficult to achieve. In the vast majority, uncomplicated infections involve and are limited to superficial skin layers, unlike complicated infections, which often extend deep to the skin and may include subcutaneous and / or fascia structures. In cases where the signs and symptoms of the patient reveal a systemic spread of the infection, the optimal treatment management implies hospitalization [7-9].

From the etiopathogenic point of view skin and subcutaneous infections are divided into: primitive, secondary or are present as cutaneous symptoms of a systemic bacterial disease $[5,10,11]$.

Often the etiology of microbial infections is difficult to determine because the symptoms they produce are very similar, so isolation and identification of germs is necessary $[1,2,5,12]$.
Objectives

We conducted a microbiological study of the isolated bacterial strains, by determining their susceptibility to antibiotics and their resistance phenotypes.

\section{Experimental part \\ Material and method}

The etiology of cutaneous-mucosal infections was studied in patients who presented themselves at a private laboratory in Timisoara between January 2016 and December 2017.

There were studied 98 bacterial strains isolated from various biological products (pus from collections, wound secretions) [5, 13-17]. Bacteriological strains were investigated and antibiotic susceptibility testing was performed.

For all strains identified, antibiograms were performed except for strains of Streptococcus pyogenes, since no strains resistant to penicillins were detected, the treatment of choice for these being penicillin $\mathrm{G}$ and $\mathrm{V}$ [18-21].

In interpreting the results from the germ identification we took into account the following rules $[4,5,10,11,14]$ :

- in superficial suppurations, the obtained isolate may have clinical significance or may be a contaminant;

- deep and closed suppurations are often monobacterial and do not pose problems of interpretation;

- in quantitative isolation from wounds and burns, isolates in the amount $\geq 10^{5} \mathrm{UFC} / \mathrm{swab}$ have clinical significance; 
isolates in amounts of $10^{3-4} \mathrm{UFC} / \mathrm{g}$ of tissue have clinical significance if the histopathological examination confirms the presence of inflammatory infiltrates, vasculitis and thrombosis lesions;

- $\beta$-haemolytic streptococci have clinical significance regardless of the amount of their isolation $[2,4,5,22,23]$.

After bacterial identification, sensitivity testing to antibiotics was realized using Kirby-Bauer disc diffusion according to the CLSI standard [14, 23, 24]. Antibiogram was performed for all strains except for Streptococcus pyogenes - to which no penicillin-resistantstrains have been reported [22-25].

By interpreting the antibiograms, the phenotypes of resistance were determined.

\section{Results and disscusions}

Most infection, as expected, were caused by Staphylococcus aureus. Of the 98 strains, the following germs were isolated in order of frequency: Staphylococcus aureus (75.52\%), Streptococcus pyogenes (11.22\%), Pseudomonas aeruginosa (7.14\%), E. coli $(4.08 \%)$ and Enterobacter spp. (2.04\%) (fig. 1).

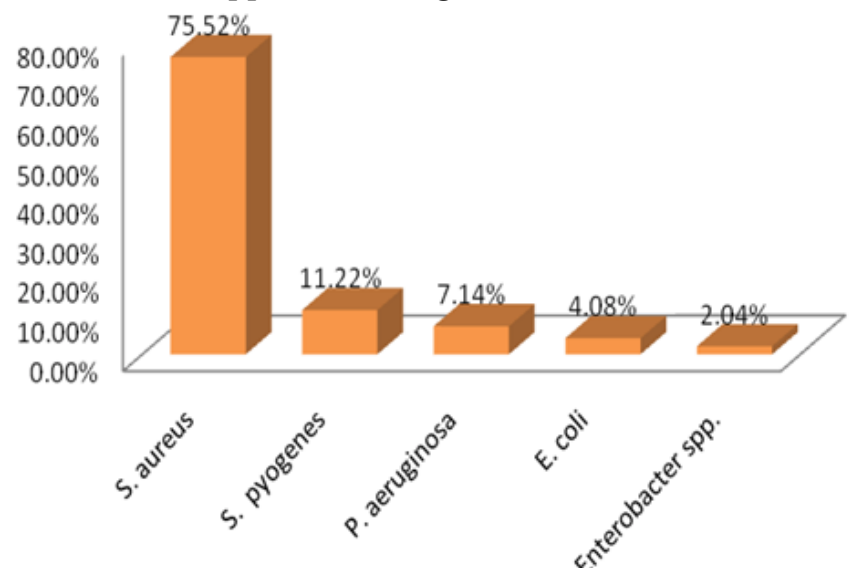

Fig. 1. Bacterial strains isolated from cutaneouns-mucosal infections

A study published in the literature [7] shows that Staphylococcus aureus is the most commonly isolated from ambulatory patients, causing up to $69 \%$ of cutaneousmucosal infections, followed by haemolytic $\beta$ streptococci (particularly group A streptococci - Streptococcus pyogenes) - 10-54\%.

In hospitalized patients, most cases are complicated infections, due to low immunity. In these cases Staphylococcus aureuswas isolated in a lower percentage - 44\%. Hospitalized patients showed a higher germ variety compared to ambulatory patients. In addition to Staphylococcus aureus, Pseudomonas aeruginosa, enterobacteria, enterococci and group A haemolytic streptococci were isolated in higher percentages compared to outpatients [7].
In hospitalized antibiotic-treated patients, antibiotic sensitive Staphylococcus aureus strains can be replaced with resistant or multi-resistant germs [7, 26, 27].

Antibiotic sensitivity was tested in all isolates except $S$. pyogenes $[2,4,5,22,23,26]$.

The strains of $S$. aureus had the following characteristics:

- $94.60 \%$ were resistant to penicillin, most of the strains being penicillinase producing;

- intermediate sensitivity we determined for: kanamycin $(60.81 \%)$, erythromycin $(70.27 \%)$ and trimethoprimsulfamethoxazole ( $71.62 \%)$;

- they were susceptible to: oxacillin (87.84\%), tobramycin $(86.49 \%)$, gentamicin $(87.84 \%)$, ciprofloxacin $(83.78 \%)$ and clindamycin (89.20\%).

Interpretative analysis of antibiograms allowed stratification of $S$. aureus strains in resistance phenotypes.

By determining the antibiotic resistance phenotypes, information on the mechanism of antibiotic resistance can be obtained and the substances with which the test bacteria is resistant can be deduced - based on these mechanisms [26, 28-30].

Three phenotypes of beta-lactam resistance are found in S. aureus: Peni-S Meti-S, Peni-R Meti-S, Peni-R Meti-R (MRSA) $[26,28,29]$. Most of the isolated strains fell into the Peni-R Meti-S phenotype (61 strains - 82.44\%). 9 strains (12.16\%) fell into the Peni-R Meti-R phenotype (MRSA) and only 4 strains $(5.40 \%)$ were sensitive to betalactamins (Peni-S Meti-S) (fig. 2).

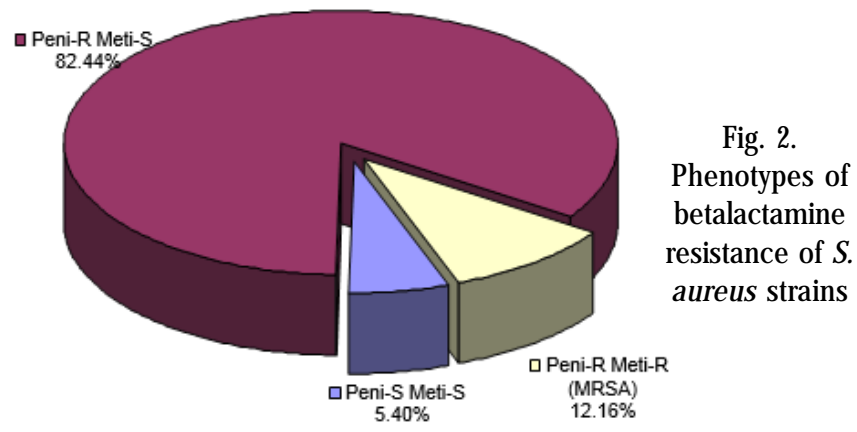

The presence of MRSA at a rate of $12.16 \%$ is an alarm signal because the MRSA strains are multi-resistant to antibiotics with cross-resistance to the betalactams. Resistance usualy extends also to other classes of antibiotics [27, 28].

For the determination of the three aminoglycoside resistance phenotypes ( $K, K T, K T G)$, kanamycin, tobramycin and gentamycin were used, depending on which susceptibility to amikacin and netilmicin was deduced (fig. 3) [28].

The phenotype $\mathrm{K}$ (kanamycin resistance) reported in $25.68 \%$ of the strains, as well as the KT phenotype (kanamycin resistance and tobramycin), found in $1.35 \%$ of the strains, are predictive of resistance to amikacin; netilmicin remaining active [28].

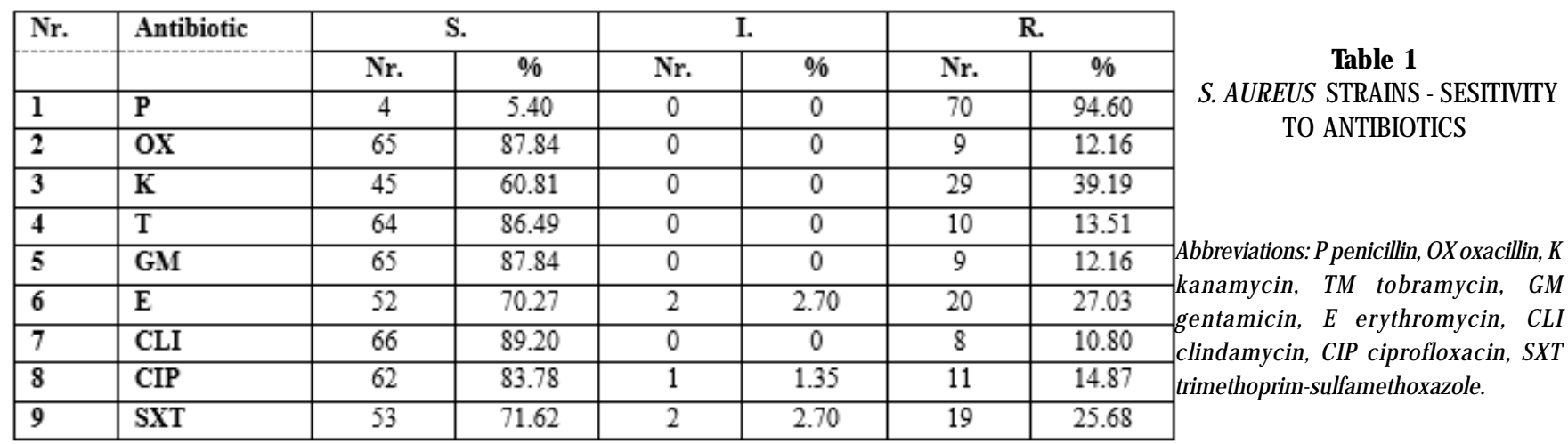




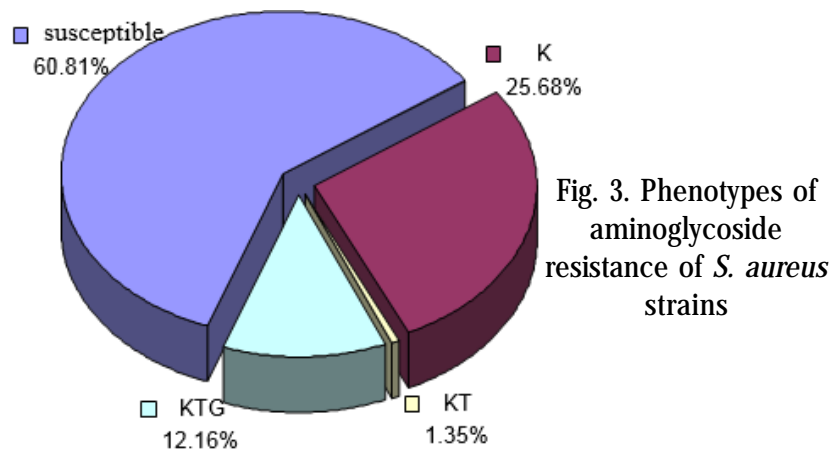

Resistance to kanamycin, tobramycin and gentamycin (KTG phenotype) present in $12.16 \%$ of the strains is predictive of resistance to amikacin and netilmicin [28].

For the determination of resistance to MLS (macrolides, lincosamide, streptogramins), the erythromycin association with clindamine was tested by disc diffusion. Phenotypic expression of resistance may be inducible or constitutive: MLSB inducible phenotype, MLSB constitutive phenotype [24-27].

Of $22(29.73 \%)$ resistant strains, $21(28.38 \%)$ presented the MLSB phenotype: 13 (17.57\%) - MLSB inducible phenotype and 8 (10.81\%) - MLSB constitutive phenotype. An antibiotic efflux resistance was observed in a (1.35\%) strain of S. aureus (phenotype M) (fig. 4).

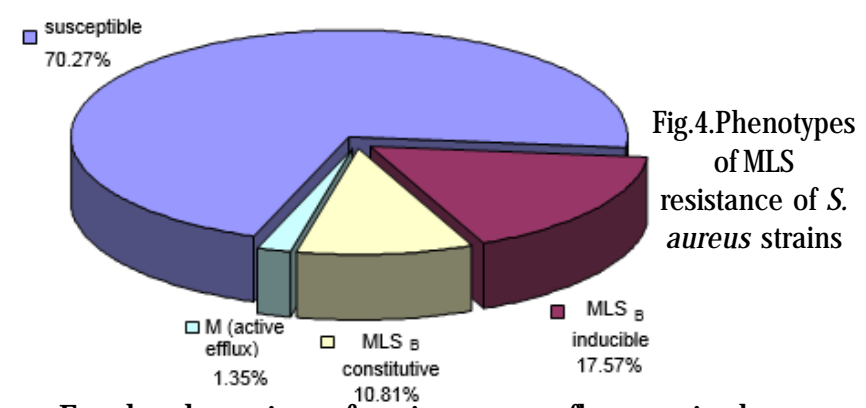

For the detection of resistance to fluoroquinolones, a single quinolone was used - ciprofloxacin, staphylococci having cross-resistance to all fluoroquinolones [28]. Most of the strains were sensitive $-83.78 \%$, a small part gained resistance - $16.22 \%$ (fig. 5).

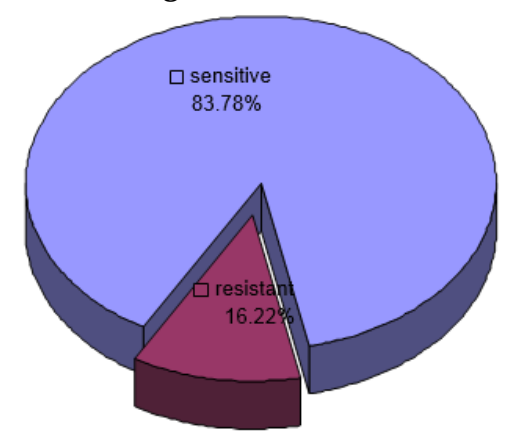

Fig. 5 Phenotypes of fluoroquinolones resistance of $S$. aureus strains

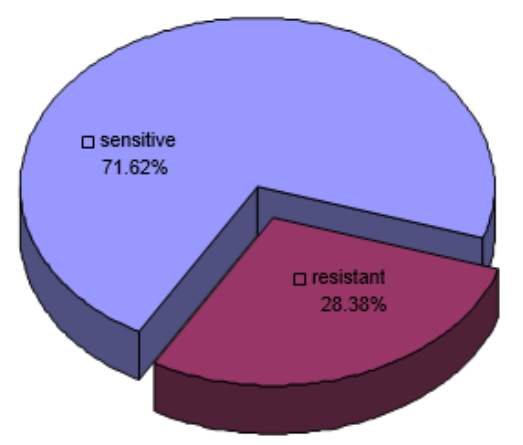

Fig. 6. Phenotypes of trimetroprim-

sulfamethoxazole resistance of $S$. aureus strains
At trimetroprim-sulfamethoxazole $71.62 \%$ of the strains were susceptible, the remaining $28.38 \%$ being resistant (fig. 6).

Taking into account gram-negative bacterial strains isolated from cutaneous-mucosal infections (Pseudomonas aeruginosa, E. coli, Enterobacterspp.), they were less resistant, all of them being wild strains with natural sensitivity to antibiotics preserved.

\section{Conclusions}

Establishing antibiotic resistance phenotypes is necessary in order to be able to make the right decision in choosing anti-infectious treatment, but also to prevent the selection of multi-resistant bacterial strains.

Isolation in outpatient patients of $12.16 \%$ of MRSA strains is an alarm signal because they are multi-resistant to antibiotics with cross-resistance to the betalactamine complex, and the resistance usually extends to other classes of antibiotics.

Taking into account the isolation of multi-resistant strains, it is necessary to target antimicrobial agents based on antibiograms and to implement an epidemiological surveillance system of the resistance phenomenon.

No antibiogram was performed in isolated strains of Streptococcus pyogenes because its natural sensitivity to penicillin is unanimously recognized. The choice of treatment is Penicillin G and Penicillin V. The choice for penicillin allergic patients are macrolides, eg erythromycin, clarithromycin.

To establish the diagnosis and therapeutic plan, the results of the bacteriological examination are corroborated with the clinical signs.

\section{References}

1.ANGELESCU M., Terapia cu antibiotice, Ed. Medicala, Bucuresti, 1998, p. 510-514, 505-525.

2.ERON L.J., LIPSKY B.A., LOW D.E. et al., Managing skin and soft tissue infections: expert panel recommendations on key decision points, J. Antimicrob. Chemother. 52(Suppl 1), 2003, p. i3-i17.

3.SMITH A.J ., DANIELS T., BOHNEN J.M.A., Soft tissue infections and the diabetic foot, Am. J. Surg., 172 (Suppl 6S),1996, p. 7S-12S.

4.BUIUC D., Microbiologie medicala, Ed. Didactica si Pedagogica Bucuresti, 1992, p. 399-407.

5.BUIUC D., NEGUT M. si col., Tratat de microbiologie clinica, editia a 3-a, Ed. Medicalã, Bucure-ti, 2009, p. 195-207.

6.HOLTMANN H., NITSCHKE J ., Medizinische Mikrobiologie, Hygiene und Infektiologie, editia a 4-a, Ed. Elsevier GmbH Deutschland, 2017, p. 152-153.

7.ALDRIDGE K.E., PANKEY G.A., RODLOFF A.C., Complicated Skin and Skin Structure Infections, Ed. Current Medicine Group Ltd, Londra, 2006, p. 1-20.

8.DUGAESESCU D., Microbiologie clinica, Ed. Eurostampa, Timisoara, 2013, p. 206-212.

9.HEYMANN D.L, Manual de management al bolilor transmisibile, Ed. Amaltea, Bucuresti, 2012, p.385-398.

10.BUIUC D., Microbiologie clinica, Ed. Didactica si Pedagogica, Bucuresti, 1998, p. 200-213.

11.BUIUC D., Microbiologie medicala: ghid pentru studiul si practica medicinei, Ed.Gr. T. Popa lasi, 2003, 383-386.

12.FUNG H.B., CHANG J.Y., KUCZYNSKI S., A practical guide to the treatement of complicated skin and soft tissue infections, 63, Drugs, 2003, p. 1459-1480.

13.MOLDOVAN R., LICKER M., DOROIU M., BERCEANU-VADUVA D. si colab., Microbiologie- îndreptar de lucrãri practice, lito UMFT, 2002, p. 106-115.

14.DUMITRASCU V., LICKER M., GRECU D.S.,VLAD D.C., BERCEANUVADUVA D. si col., Ghiduri si protocoale in medicina de laborator, sub redactia Dumitrascu V, Ed. de Vest, 2010, p. 83-88, 89-99. 
15.STANCU, A., ROMEO, C., AHMADI, M., CÃRPINISAN, L., GHISE, A., PENTEA ,M., BERCEANU-VÃDUVA, D.M., Hematoxylin - eosinmethylene Blue Staining in a Dog Hemangiosarcoma Case, Mat. Plast., 52, no. 4, 2015, p. 514-515.

16.STANCU, A., CÃRPINISAN, L., GHISE, A., PENTEA ,M., BERCEANUVÃDUVA, D.M., VELIMIROVICI, D.E., ROMEO, C., Hematoxylin - eosinmethylene Blue Staining in a Dog Hepatic Amyloidosis Case, Mat. Plast., 54, no. 3, 2017, p. 546-548.

17.STANCU, A., GHISE, A., PENTEA, M, VELIMIROVICI D.E., CARPINISAN, L., CRISTINA, R., Mat. Plast., 54, no. 4, 2017, p. 785-787 18.DEBELEAC L.; POPESCU DRANDA M.C., Microbiologie, Ed. Medicala Amaltea, 1994, 121-124.

19.INGLIS T.J. . ., Microbiology and Infection. Churchill Livingstone, editia a 2-a, 2007, p. 65-71.

20.ANGHELESCU E., LAZAR Z., RADUa S., CRACIUNESCU M., BERCEANU VADUVA D.M., Bacteriologie medicala, Ed. Mirton, 1996, p. 49-63.

21.ANGHELESCU E., LAZAR Z., BERCEANU-VADUVA D.M., IACOBICIU I., CHIUARIU D., PACURARIU G., Microbiologie-Bacteriologie, Ed. Presa Universitara Romana, 1997, p. 100-114.

22.MOLDOVAN R., DOROIU M., RADUS S., LICKER M., CRACIUNESCU M., BERCEANU-VADUVA D. si colab., Bacteriologie practica, Ed. Mirton, Timisoara, 1998, p. 93-102.
23.MOLDOVAN R., LICKER M., CRACIUNESCU M., BERCEANU-VADUVA D., HOGEA E., DUGAESESCU D., Lucrari practice de microbiologie, Ed. Victor Babes, Timisoara, 2013, p. 33, 84.

24.*** CLSI -Performance Standards for Antimicrobial Disk Susceptibility Tests; Approved Standard M02, M100-Clinical and Laboratory Standards Institute, USA 2015, 2016.

25.*** Ghid national pentru aplicarea procedurii de testare a sensibilitatii la antibiotice conform Standardului CLSI/NCCLS Publicatie a Laboratorului National de Referinta pentru Infectii Nosocomiale si Rezistenta la Antibiotice din Cadrul Institutului National de Cercetare-Dezvoltare pentru Microbiologie si Imunologie Cantacuzino Bucuresti, Versiunea 0 - Pentru Consens National, 2005. 26.LICKER M., NICOARA E. si colab., Ghid pentru preventia multirezistentei bacteriene. Ed. Eurobit, Timisora, 2011, p. 12-19.

27.MOLDOVAN R., LICKER M., BERCEANU VADUVA D. si colab. - Curs de microbiologie speciala - vol. I-bacteriologie, Ed. Victor Babes, Timi-oara, 2013, p. 11-23, 35.

28.J EHL F., CHOMARAT M., WEBER M., GERARD A., De la antibiograma la prescriptie, Ed. Stiintelor Medicale, Bucuresti, 2004, p. 32-41, 80-85. 29.LICKER M., MOLDOVAN R. CRACIUNESCU M., DUMITRASCU V., Rezistenpa la antibiotice, istorie si actualitate, Ed. Eurostampa, Timisoara, 2002, p. 108-119.

30.MOLDOVAN R., LICKER M., HOGEA E., BADIOIU L., Microbiologie generala, Ed. Victor Babes Timisoara, 2015, p. 215-217.

Manuscript received: 21.05.2018 